\title{
Комп'ютерні технології в методиці формування творчої самореалізації магістрантів
}

\begin{abstract}
Досліджено питання впровадження комп’ютерних технологій у процес формування творчої самореалізації магістрантів музичного мистецтва під час вивчення циклу диригентсько-хорових дисциплін у вищому педагогічному навчальному закладі. Охарактеризована сутність фахової підготовки студентів до музично-педагогічної діяльності з учнями загальноосвітньої школи, а саме проведення вокально-хорової роботи на уроках музичного мистецтва. Запропоновані навчальні методи спрямовані на формування творчої самореалізації магістрантів музичного мистецтва. Використання комп'ютерних технологій здійснюється порівняно з вирішенням організаційних, методичних і навчальних завдань під час музично-педагогічної діяльності вчителя музичного мистецтва зі школярами. Виявлена необхідність оволодіння магістрантами музичного мистецтва навчальними методами, що передбачає широке використання можливостей засобів мультимедіа, комп'ютерних технологій, залучення учнів до евристичної діяльності. Обгрунтована гіпотеза, що використання комп’ютерних технологій в музичному навчанні підвищить мотивацію студентів до творчої самореалізації.
\end{abstract}

Ключові слова: творча самореалізація; магістрант музичного мистецтва; комп’ютерні технології.

Сьогодні в Україні відбувається становлення нової системи музичної освіти. Те, що наприкінці XX століття «сприймалося як плюралізм, змішення стилів, ідей, гіпотез, сьогодні починає набувати впорядкованої форми, виявляє властивості парадигми. I це не лінійний перехід до наступного етапу, а якісний стрибок. Нова парадигматика, порівняно із попередньою, виступає як об’єднуюча система більш високого рівня. Це дійсно зрушення на порядок вище» [1, с. 5]. Поряд із традиційними музично-педагогічними технологіями використовуються і комп'ютерні технології, що сприяють розвитку інтелектуальних умінь магістрантів музичного мистецтва, їх музичних здібностей, а також творчій самореалізації у навчанні. Під час фахового навчання магістранти музичного мистецтва обов'язково вивчають такі базові комп'ютерні програми як: нотний редактор Sibelius; Instruments для набуття вміння щодо здійснення інструментовки; електронний курс аналізу музичних форм i композиції Compass; Auralia та Musition для підвищення музично-теоретичних знань; Star Class для підготовки до проведення уроків музичного мистецтва. Критеріями оцінки самостійної творчої діяльності студентів із використанням комп'ютерних програм має бути музичний продукт, який створений студентом самостійно.

Теоретичну основу дослідження складають праці таких дослідників як Л. Масол, О. Мозгальова, О. Олексюк, Г. Падалка, В. Ражников, О. Рудницька, О. Теплова, Г. Хусаїнова, О. Щолокова та ін., які, розглядаючи питання щодо творчої самореалізації майбутніх учителів мистецьких дисциплін, розробили способи їх активізації у навчанні, організаційно-методичні засоби реалізації творчих можливостей студентів. Проблема використання комп'ютерних технологій у навчальному процесі певною мірою висвітлена в працях Ю. Бабанського, І. Гиркіна, Е. Грих, Р. Гуревич, І. Захарової, Н. Желябіної, О. Коберника та ін. Однак питання застосування засобів мультимедіа і сучасних комп'ютерних технологій в процесі підготовки магістрантів музичного мистецтва до творчої самореалізації у музично-педагогічній діяльності не достатньо представлено у наукових педагогічних матеріалах.

Мет ю ю татті $є$ проаналізувати особливості використання комп'ютерних технологій в методиці формування творчої самореалізації магістрантів музичного мистецтва. 3 а в данн я дослідження : розглянути можливості використання комп'ютерних технологій у фаховому розвитку магістрантів музичного мистецтва; проаналізувати навчальні методи щодо вокально-хорового розвитку школярів на уроках музичного мистецтва з використанням комп'ютерних технологій; розробити авторські навчальні методи формування творчої самореалізації магістрантів музичного мистецтва. 
Формування творчої самореалізації у магістрантів музичного мистецтва як потреби в процесі диригентсько-хорового навчання у вищому навчальному закладі здійснюється поступово та систематично. У цьому процесі студенти потребують цілеспрямованої педагогічної підтримки. До навчальної методики формування творчої самореалізації магістрантів музичного мистецтва нами включено навчальні методи, що передбачають використання можливостей сучасних комп'ютерних технологій, а саме: метод фрагментарної обробки даних; метод «Емоційні віражі»; проблемний метод; метод професійно-проблемного рефлексування; метод цілеспрямованого впливу на процес сприйняття учнями хорових творів; метод «Творчий пошук»; метод вирішення творчих завдань; методу комплексного використання сучасних комп’ютерних технологій.

Під час музично-педагогічної діяльності 3 учнями загальноосвітньої школи вчитель музичного мистецтва має прищеплювати любов до хорового мистецтва виявляючи свою обізнаність у галузі хорової музики. Це передбачає дотримання принципу систематичності та послідовності. Методом фрагментарної обробки даних уможливлюється залучення магістрантів музичного мистецтва до використання можливостей комп'ютерних технологій. Softonic для створення навчальної наочності інтерактивного характеру. За даним методом викладач залучає студентів до самостійної роботи за допомогою комп'ютеру й можливостей міжнародної мережі Інтернет. Студенти здійснюючи пошук відеозапису виступів дитячих вокально-хорових колективів опрацьовують бланк «Самостійна робота над відеорядом». Так, обраний відео фрагмент студент опрацьовує занотовуючи назву відео, виконавського колективу, назву хорового твору й авторів. Це також передбачає визначення часу тривалості певного відео фрагменту. У цьому процесі студенти використовують набуті інтелектуальнологічні вміння щодо систематизації, класифікації, конкретизування, узагальнення, синтезування, аналогій, порівняння даних. Комп'ютерна технологія Softonic уможливлює опрацювання відео вилученого з You Tube визначаючи час демонстрації відео із додаванням спеціальних ефектів. Це уможливлює побудову відеоряду в такому порядку як «відео-тексткартинка». Для створення музичного супроводу певного тексту чи картинки дана технологія пропонує обрати користувачу аудіо файл і опрацювати дані. Отриманий результат самостійної навчальної роботи магістранти музичного мистецтва експортують решті студентів для того, щоб навчитись експортувати учням у подальшій музично-педагогічній діяльності. Залучення методу фрагментарної обробки даних до процесу спонукання студентів до виявлення обізнаності у галузі хорової музики сприяло ознайомленню їх із можливостями такої комп'ютерної технології як Softonic. Створюючи умови для самостійної навчальної роботи студентів засобами мультимедіа викладач спонукав їх до виявлення обізнаності у галузі хорової музики завдяки творчої діяльності з даними.

Слід сказати, що вчитель музичного мистецтва, залучаючи учнів до позаурочної навчальної діяльності, готує їх до виступів під час проведення тематичних позаурочних заходів, шкільних концертів. Серед інших концертних номерів учні здатні представити інсценізацію пісні, уривок із дитячої опери чи мюзиклу. Ці номери передбачають колективний спів учнів, який має бути емоційно виразним. Організація вокально-хорової роботи школярів передбачає виявлення вчителем музичного мистецтва здатності емоційно впливати на них для досягнення ефективності цієї позаурочної діяльності. 3 цією метою нами до експериментальної методики формування творчої самореалізації магістрантів музичного мистецтва було введено метод «Емоційні віражі». Цей метод передбачає створення умов для набуття магістрантами музичного мистецтва умінь організації вокально-хорової роботи учнів у позаурочний час із використанням сучасної комп'ютерної технології Google Classroom. Викладач організовуючи навчальну діяльність студентів за допомогою комп'ютерів сприяє навчальній роботі з використанням можливостей комп'ютерної технології Google Classroom, де кожен студент працюючи самостійно створює свій курс «Позаурочна діяльність учнів» $\mathrm{i}$ приєднує до цієї групи усіх учасників, залучених до експериментальної роботи. У віконці «обрати тему» кожен студент вводить назву хорового твору, призначеного для дитячого 
хорового колективу, а також створює фон сторінки, щоб зацікавити учнів процесом підготовки до концертного виступу. Це передбачало залучення магістрантів музичного мистецтва до створення навчального завдання, яке вимагало використання креативного мислення, набутих фахових умінь. Скориставшись можливостями цієї технології, студенти мають можливість створити педагогічний рисунок і «роздати» його учням. Позначка «гугл диск» уможливлює використання з навчальною метою даних, вже збережених студентом на його «гугл диску». Для здійснення сугестивного впливу на учнів магістранти музичного мистецтва здійснюють пошук в Yоu Тube необхідного відеоряду і розташовують його на сторінці свого курсу. Залучення магістрантів музичного мистецтва до навчальної роботи за даним методом сприяло формуванню їх культури щодо використання сучасної інформаційної техніки. Набуваючи вмінь щодо організації вокально-хорової роботи учнів, студенти навчались використовувати можливості комп'ютерної технології Google Classroom i координувати інформаційний потік у процесі підготовчої роботи учнів до участі у концертному виступі в шкільному заході. Здійснюючи навчальну творчу діяльність, студенти навчались здійснювати сугестивний вплив на учнів засобами звуку, анімації, відео, графіки, тексту для збагачення емоційної сфери учнів.

Для підготовки студентів до застосування фахових знань під час використання засобів мультимедіа ми використали проблемний метод. Організація навчальної діяльності магістрантів музичного мистецтва передбачала постановку викладачем навчальної проблеми, що поставала у розробці навчальних тестів для учнів шкільного віку. Ці тести мають бути спрямовані на здійснення діагностики набутих знань учнів щодо вокально-хорової роботи над шкільною піснею. Викладач залучає студентів до використання можливостей комп'ютерної технології Learning Apps.org для розробки навчальних тестів щодо правильності виконання співацьких дій під час вокально-хорової роботи над шкільною піснею на уроках музичного мистецтва. Студенти оволодівають уміннями створювати тести й експортувати їх на електронні адреси учнів для того, щоб вони відтворили, повторили, опрацювали навчальний матеріал. Ця комп'ютерна технологія передбачає використання Blank Quiz, для створення анкети чи тесту. Кожен студент, виконавши навчальне завдання, експортує його іншим учасникам експериментального дослідження, які заповнюють анкету чи тест, а комп’ютерна програма обробляє отримані дані та підраховує середній бал. Таким чином, за допомогою даного методу викладач залучає студентів до навчальної роботи 3 використанням такої комп'ютерної технології як Learning Apps.org для набуття ними вміння створювати анкети й тести щодо проведення діагностики набутих знань учнів щодо правильних співацьких дій.

Необхідність формування в магістрантів музичного мистецтва позитивного ставлення до творчої самореалізації обумовлюється важливістю їх фахового розвитку під час навчання у вищому навчальному закладі. Ми враховували думку А. Маслоу щодо розуміння самореалізації особистості, як процесу поступового накопичення творчих досягнень [5]. До експериментальної методики ми включили метод професійно-проблемного рефлексування, який сприяє вирішенню магістрантами музичного мистецтва навчального завдання 3 використанням мультимедійних технологій. Спочатку, студенти залучаються до самостійного заповнення бланку «Мої особистісні творчі досягнення». Кожен магістрант музичного мистецтва заповнюючи даний бланк під час саморефлексії обов'язково здійснює само оцінювання, та заповнює графу «Планування творчої самореалізації під час навчання у вищому навчальному закладі». Серед наступних завдань щодо залучення магістрантів музичного мистецтва до навчальної роботи за методом професійно-проблемного рефлексування постає спонукання їх до усвідомлення ними своїх творчих можливостей. Для цього викладач пропонує студентам проаналізувати свій заповнений бланк та виявити ті складові музично-творчої самореалізації, які раніше не брались до уваги, однак сприятимуть у подальшому творчій самореалізації у музично-педагогічній діяльності. Результатом професійно-проблемного рефлексування постає створення ментальної карти «Підвищення 
індивідуального рівня фахового розвитку» за допомогою мультимедійної технології Word Art. Залучення магістрантів музичного мистецтва до навчальної роботи за даним методом сприяло залученню їх до саморефлексії, виявленню фактів здійснення творчої самореалізації під час фахового навчання у вищому навчальному закладі, аналізу своїх творчих можливостей із постановки навчальної проблеми щодо підвищення індивідуального рівня розвитку для творчої самореалізації в умовах навчального процесу.

Доречно зазначити, що вчителю музичного мистецтва необхідно готувати учнів до сприйняття хорових творів, формуючи їх художньо-естетичні враження. Враховуючи це, ми до експериментальної методики ввели метод цілеспрямованого впливу на процес сприйняття учнями хорових творів. Виходячи з того, що хорове мистецтво у XXI столітті набуває розвитку, і сьогодні створено багато хорових колективів, які працюють в певних стилях викладач, використовуючи групову форму навчання, розподіляє студентів на декілька малих груп. Кожна створена група самостійно обирає хоровий стиль, якого буде дотримуватись під час виконання навчального завдання. Далі учасники кожної групи обирають відеоматеріал, який включає хорове звучання в певному хоровому стилі. Залучаючи студентів до евристичної діяльності, викладач спонукає їх до пошуку способів посилення художньо-естетичного враження від сприйняття хорового звучання. Магістранти музичного мистецтва мають усвідомити необхідність проведення учителем музичного мистецтва підготовчої роботи до формування художньо-естетичних вражень учнів на уроках музичного мистецтва. Для охоплення студентами важливих елементів такої підготовки необхідним постає створення ментальної карти з використанням комп'ютерної технології Word Art. Однак це потребує наявності плану щодо створення ментальної карти, до якого студенти занотовують необхідні дані, й далі розробляють навчальні завдання та вправи для школярів. Залучення магістрантів музичного мистецтва до навчальної роботи за даним методом сприяло усвідомленню необхідності формування художньо-естетичних знань. Навчальна робота з відеоматеріалом уможливила проведення студентами аналізу хорового звучання для пошуку способів педагогічного впливу на учнів під час сприйняття даних. Накопичення студентами візуального та слухового досвіду здійснювалось порівняно із розробкою навчальних завдань і вправ для учнів, які сприяти муть їх підготовці для сприйняття хорового звучання.

3 метою залучення магістрантів музичного мистецтва до практичного використання фахових знань і вмінь у самостійній навчальній роботі ми до експериментальної методики включили метод «Творчий пошук». Цей метод передбачає залучення студентів до створення творчих завдань, які призначені для поза аудиторної самостійної роботи учнів. Порівняно із цим, кожен студент під час самостійної роботи заповнює бланк «План виконання самостійної навчальної діяльності, до якого занотовується назва творчого завдання, навчальна мета й завдання, а також рекомендації вчителя щодо виконання творчого завдання. Поряд із тим студенти мають враховувати те, що учні виконують ці творчі завдання із виявленням різного рівня вокально-хорового розвитку. Так, на початковому рівні учні виявляють лише репродуктивне відтворення, що передбачає спів пісні в караоке, вибір одного варіанту із запропонованого тощо. На розвинутому рівні учні здатні здійснювати доповнення до творчого продукту. Під час самостійної навчальної діяльності студенти створювали предметну інтернет-сторінку за допомогою комп'ютерної технології Google classroom, до якої необхідно приєднати учнів та експортувати їм розроблені самостійно певні творчі завдання. Роль учнів виконувала решта студентів, які аналізували отримані дані за допомогою мережі Інтернет. Викладач залучав студентів до загального обговорення результатів самостійної навчальної роботи. Залучення магістрантів музичного мистецтва до здійснення самостійної навчальної роботи за даним методом уможливило спрямування до творчої навчальної діяльності, що передбачало врахування різних рівнів вокально-хорового розвитку учнів, а також використання можливостей комп'ютерної технології Google classroom. 
Методом вирішення творчих завдань уможливлюється залучення магістрантів музичного мистецтва до творчої навчальної діяльності з використанням інноваційних педагогічних технологій, а також комп'ютерної технології. Останнє ми обрали Online Test $\mathrm{Pad}$. Ця комп'ютерна технологія передбачає використання конструктору опитування. Викладач залучав магістрантів музичного мистецтва розробляти музичні он-лайн кросворди, а також логічні ігри, які сприяють розумінню учнями музичних понять і термінів.

Підготовлення магістрантів музичного мистецтва до застосування фахових знань під час використання можливостей засобів мультимедіа здійснювалось із використанням методу комплексного використання сучасних комп'ютерних технологій. Цей метод передбачає організацію викладачем самостійної навчальної діяльності студентів спрямованої на використання сучасних комп'ютерних технологій для набуття практичних умінь обробляти текстову, цифрову, графічну і звукову інформацію за допомогою відповідних програм i редакторів для підготовки дидактичних матеріалів (варіанти завдань, таблиці, схеми, малюнки). Така навчальна діяльність магістрантів музичного мистецтва спрямована на розробку таких типів навчальних завдань для учнів під час залучення їх до вокально-хорової роботи: 1) умовно-творчі: слухання, малювання, добір складових до відомого; 2) навчальнотворчі: спрямовані на творче вирішення навчального завдання; 3) евристичні: передбачають забезпечення учнів навчальними наочними засобами.

Залучення магістрантів музичного мистецтва до навчальної роботи за методом комплексного використання сучасних комп'ютерних технологій сприяло їх підготовці до застосування фахових знань, а також залученню їх до творчої діяльності спрямованої на створення навчально-методичного матеріалу для вокально-хорової роботи 3 учнями загальноосвітньої школи.

Висновки. Підсумовуючи зазначене вище слід підкреслити, що сучасний вчитель музичного мистецтва має володіти інформаційно-комп'ютерними технологіями для впровадження музично-педагогічних інновацій у процес музично-естетичного розвитку учнів. Завдяки представленим навчальним методам, які включено до методики формування творчої самореалізації магістрантів музичного мистецтва, студенти навчаються подавати навчальний матеріал школярам на уроках музичного мистецтва в електронній формі, використовуючи компактність навчального наочного матеріалу, а також можливості залучення учнів до інтерактивної навчальної діяльності.

\section{Література}

1. Герасимова-Персидськая Н. Музыка. Время. Пространство. Київ : Дух і літера, 2012. 408 с.

2. Гиркин I. В. Нові підходи до організації учбового процесу з використанням сучасних комп’ютерних технологій. Інформаційні технології № 6, 2008. С. 25-31.

3. Гуревич Р. С. Інформаційно-комунікаційні технології у навчальному процесі : Посібник для педагогічних працівників і студентів педагогічних вищих навчальних закладів. Вінниця : ДОВ «Вінниця», 2002. $116 \mathrm{c.}$

4. Захарова І. Г. Інформаційні технології в освіті: навчальний посібник для вищ. навч. закладів. Київ : Академія, 2008. 188 с.

5. Маслоу А. Новые рубежи человеческой природы. Москва : Смысл, 1999. 423 с.

6. Олексюк О. М., Ткач М. М. Музично-педагогічний процес у вищій школі. Київ : Знання України, 2009. $123 \mathrm{c.}$

7. Падалка Г. М. Творча самореалізація в мистецтві : теоретико-педагогічні аспекти. Науковий часопис Національного педагогічного університету імені М. П. Драгоманова. Сер. 14. Теорія $i$ методика мистеиької освіти. 2015. Вип. 18 (23). 342 с.

Про автора:

Вей Лімін, доцент кафедри теорії та методики музичної освіти, хорового співу і диригування факультету мистецтв імені Анатолія Авдієвського Національного педагогічного університету імені М.П. Драгоманова; e-mail: 2506077@gg.com 


\section{Computer technologies in the method of formation of creative self-realization of masters}

Wei Limin

Relevance of the study. Today a new system of music education is emerging in Ukraine. Changes in the pedagogical theory and practice of the educational process are aimed at stimulating students to acquire professional competencies, and to give them independent work of creative, problematic and research character. In addition to traditional music-pedagogical technologies, computer technologies are also used to promote the intellectual skills of undergraduate musicians, their musical abilities, and creative self-realization in teaching. The purpose of the article is to analyze the peculiarities of the use of computer technologies in the method of formation of creative self-realization of undergraduates of musical art. Objective of the article: to consider the possibilities of computer technologies in the professional development of undergraduates of musical art; to analyze teaching methods on vocal and choral development of pupils in music lessons using computer technologies; to develop author's educational methods of forming the creative self-realization of undergraduates of musical art. Research methods: theoretical, empirical. Results. Educational methods of forming the creative self-realization of undergraduates of musical art include educational methods that involve the use of modern computer technologies, namely: the method of fragmentary data processing; method «Emotional curves»; problematic method; method of professional-problematic reflection; method of purposeful influence on the process of students' perception of choral works; the Creative search method; method of solving creative problems; a method of integrated use of modern computer technology. Discussion. The issue of using multimedia and modern computer technology in the preparation of undergraduate music students is not sufficiently presented in scientific pedagogical materials. Findings. The necessity of mastering music undergraduates was revealed by the teaching methods, which involve the use of opportunities of multimedia, computer technologies, involvement of students in heuristic educational activity. The hypothesis that the use of computer technologies in music training will increase students' motivation for creative self-realization both in teaching and in future music-pedagogical activity is substantiated. Originality. The author's educational methods of forming the creative self-realization of undergraduates of musical art have been developed. Conclusions. Thanks to the presented teaching methods, which are included in the method of forming the creative self-realization of the undergraduates of music art, students learn to submit educational material to students in music art lessons in electronic form, using the compactness of educational visual material, as well as the possibility of involving students in interactive educational activities. By mastering certain teaching methods, undergraduates of musical art learn to intensify the process of mastering students vocal and choral skills, to encourage them to music and creative activity. Significance. The author's educational methods of formation of creative self-realization to conductor-choral training of undergraduates of musical art are introduced.

Keywords: creative self-realization; master of music arts; computer technology.

\section{References}

1. Gerasimova-Persydska N. Muzyka. Vremia. Prostranstvo. Kyiv : Duh i litera, 2012. 408 p. [in Ukrainian].

2. Girkin I. V. Novi pidchody do organizacii uchbovogo procesu z vykorystaniam suchasnyh komputernyh tehnologij. [New approaches to the organization of educational process with the use of modern computer technologies]. Informacijni tehnologii No 6, Kyiv. 2008. pp. 25-31. [in Ukrainian].

3. Gurevich R. S. Informacyjno-komunikacijni tehnologii u navchalnomu procesi : Posibnyk dla pedagogichnyh pracivnykiv i studentiv pedagogichnyh vyshchyh navchalnyh zakladiv. Vinnyca: DOV «Vinnyca», 2002. 116 p. [in Ukrainian].

4. Zaharova I. G. Informacijni tehnologii v osviti : navchalny posibnyk dla vysh. navch. zakladiv. Kyiv : Akademia, 2008. 188 p. [in Ukrainian].

5. Maslou A. Novyje rubezhy chelovecheskoj prirody. Moskva : Smysl, 1999. 423 p. [in Russian].

6. Oleksiuk O. M., Tkach M. M. Muzychno-pedagogichny process u vyshij shkoli. Kyiv : Znania Ukrainy, 2009. 123 p. [in Ukrainian].

7. Padalka G. M. Tvorcha samorealizacia v mystectvi : teoretyko-pedagogichni aspekty. [Creative selfrealization in art: theoretical and pedagogical aspects]. Naukovy chasopys Nacionalnogo pedagogichnogo universytetu imeni M. P. Dragomanova. Ser. 14. Teoria i metodyka mysteckoji osvity. 2015. No 18 (23). [in Ukrainian].

About the author:

Wei Limin, Associate Professor at the Faculty of arts, National Pedagogical Dragomanov University (Kyiv, Ukraine); e-mail: 2506077@gg.com 